\title{
Investigation of Dyeing Properties of Different Fabric Species with Alkanna Orientalis Root Extract
}

\author{
Adem Onal, Ferda Eser and Seda Bayrak \\ Natural Dyes Application and Research Center, Gaziosmanpasa University, Tokat 60150, Turkey
}

\begin{abstract}
In this study, the dyeing properties of different fabric species were investigated using root extract of yellow sormunen (Alkanna orientalis). For this purpose, the cotton and wool fabrics were dyed using the root extract of yellow sormunen by pre-mordanting, together-mordanting and last-mordanting methods with copper sulfate $\left(\mathrm{CuSO}_{4}\right)$, iron sulfate $\left(\mathrm{FeSO}_{4}\right)$ and aluminum sulfate $\left(\mathrm{AiK}\left(\mathrm{SO}_{4}\right)_{2}\right)$ at medium $\mathrm{pH}$. The same procedure was applied to cotton and wool fabrics that allowed in Artifical Urinary System (AUS) $\left[\% 3 \mathrm{NH}_{3}+\% 3\right.$ urea $\left.+\% 3 \mathrm{CaC}_{2} \mathrm{O}_{4(\mathrm{~g} / \mathrm{v})}\right]$ for $24 \mathrm{~h}$. The color codes were determined with Pantone Color Quide, and $\mathrm{K} / \mathrm{S}$ and $\mathrm{L}^{*} \mathrm{a}^{*} \mathrm{~b}^{*}$ values were detected with color measurement spectrophotometer, and also washing-, crocking-fastness levels were evaluated using gray scale. According to the evaluations, the fabrics dyed pre-treated with AUS have higher fastness values than the unpre-treated dyed fabrics with AUS.
\end{abstract}

Key words: Yellow sormunen, Alkanna orientalis, mordant, wool, cotton, fastness.

\section{Introduction}

Natural dyes are widely used in colouring of food substrate, natural fibres including wool, silk, cotton and leather from ancient times [1]. The usage of natural dyes in textile dyeing is increasing day by day because of the worldwide environmental consciousness [2-4]. In addition, they are non-allergic, non-toxic to human body [5]. Dyeing of fibres with the extract of the plant is generally carried out from the parts of the plant such as bark, flowers, leaves and seed. Bark is preferred in dyeing because of its high percentage of colouring agent but removal of the bark from the plant can threaten the live of the plant. For this reason, leaves, flowers and seeds are used for the extraction of the dyestuff from the plant. The leaves of the plant provide abundant and easy availability source for dyeing industry [6].

Alkanna orientalis is belonging to Alkanna boraginaceae family that is used as spice as well as dyestuff. There are 34 species endemic in Turkey [7-8]. Most of Naphtaline derivatives locate in the

Correspondence author: Adem Onal, professor, research field: organic chemistry. roots which provide red color [9].

According to the literature surveys, the dyestuff in Alkanna orientalis root is alkannin acetate [9].<smiles>COC(=O)C(CC=C(C)C)C1=CC(=O)c2c(O)ccc(O)c2C1=O</smiles>

Alkannin acetate

Ragaa et al. [10] investigated the flavonoids in root and identified their molecule structures. Tappeiner et al. [11] carried out the quantitative determinations of the alkannin/shikonin (A/S) in 11 species and compared enantiomeric ratio. Esfahani et al. [12] have investigated the anti-inflammatory and anti-nociceptive effects of the ethanolic extracts of Alkanna orientalis and Alkanna frigida on mouse and rat and, they reported that is effective on them.

Ozgokce and Yilmaz have reported that Alkanna orientalis extract has been used as dyeing of fabric and when wool yarns are treated with calcium carbonate, the color becomes smoke; when iron sulfate is used, the color becomes light green. Also, 
copper sulfate turns the color to green, when mediator substances are not used, the color of yarns becomes dark brown [13].

In this study, the dyeing properties of different fabrics species were investigated using root extract of Alkanna orientalis. For this purpose, the cotton and wool fabrics were dyed using the root extract of Alkanna orientalis by pre-mordanting, together-mordanting and last-mordanting methods using copper sulfate $\left(\mathrm{CuSO}_{4}\right)$, iron sulfate $\left(\mathrm{FeSO}_{4}\right)$ and aluminum sulfate $\left(\mathrm{AiK}\left(\mathrm{SO}_{4}\right)_{2}\right)$ at medium $\mathrm{pH}$. The same procedure was applied to cotton and wool fabrics that allowed in artificial urinary system (AUS) [\%3 $\mathrm{NH}_{3}+\% 3$ urea $\left.+\% 3 \mathrm{CaC}_{2} \mathrm{O}_{4}(\mathrm{~g} / \mathrm{v})\right]$ mixture for $24 \mathrm{~h}$. Color codes, $\mathrm{K} / \mathrm{S}$ values were determined and having high fastness dyed samples were obtained, generally.

\section{Experimental}

\subsection{Natural Dye Extraction and Mordanting}

Light, rubbing and washing fastness properties and color codes of dyed cotton fabrics are given in Table 1 . Alkanna orientalis used as a natural dye source in the present study was collected from the Tokat region (Turkey). Its roots were dried at room temperature on shade. $20 \mathrm{~g}$ of root was refluxed on soxhlet apparatus using distilled water until colorless. This procedure was applied until 5 liters of color extracts, and finally all extracts were collected.

The metal salts iron sulfate, copper sulfate and aluminum potassium sulfate were used as mordants; the dyeing procedure of the textile fabrics is pre-mordanting, together-mordanting, and last-mordanting.

\subsection{Reagents and Equipments}

All chemicals used in this work, were purchased from Merck. Distilled water was used for all steps. $\mathrm{FeSO}_{4} \cdot 7 \mathrm{H}_{2} \mathrm{O}, \quad \mathrm{AlK}\left(\mathrm{SO}_{4}\right)_{2} \cdot 12 \mathrm{H}_{2} \mathrm{O}$ and $\mathrm{CuSO}_{4} \cdot 5 \mathrm{H}_{2} \mathrm{O}$ were purchased from Merck. Extraction was performed by using soxhlet apparatus. Color codes were determined by Pantone Color Guide. The wash-, crock- (wet, dry) and light-fastnesses of all dyed samples were established according to ISO 105-C06 and to CIS, respectively, and fastness values were determined by Atlas Weather-ometer, a Launder-ometer and a 255 model crock-meter, respectively [14].

\subsection{Dyeing Procedures}

Dyeing procedures of wool and cotton samples were firstly kept in $\left(\mathrm{NH}_{3}+\mathrm{Urea}+\mathrm{CaC}_{2} \mathrm{O}_{4}\right)$ solution $3 \%$ $(\mathrm{g} / \mathrm{v})$ for $24 \mathrm{~h}$. At the end of the time, the samples rinsed with distilled water and dyed according to the dyeing methods mentioned below.

\subsubsection{Pre-mordanting Method}

The undyed material $(1 \mathrm{~g})$ was heated in $0.1 \mathrm{M}$ mordant solution $(100 \mathrm{~mL})$ for $1 \mathrm{~h}$ at $90{ }^{\circ} \mathrm{C}$. After cooling of sample, it was rinsed with distilled water

Table 1 Fastness values and color codes of dyed cotton samples.

\begin{tabular}{lllllll}
\hline Method & Mordant & $\mathrm{pH}$ & Lightfastness & Washing fastness & Rubbing (wet/dry) & Colorcode \\
\hline T1 & M1 & 4.65 & $5 / 6$ & $4 / 5$ & $5 / 5$ & 173906 GrayLil. \\
T2 & M1 & 4.65 & 6 & $5 / 5$ & $4 / 5-5$ & 171046 Golden \\
T3 & M1 & 4.65 & 6 & 5 & $4 / 5-5$ & 120813 Auntumn \\
T1 & M2 & 4.01 & $5 / 6$ & 5 & $4 / 5-5$ & 140615 GreenHaz. \\
T2 & M2 & 4.01 & 4 & 3 & $5 / 5$ & $15-3802$ CloudGr. \\
T3 & M2 & 4.01 & $6 / 7$ & 5 & $5 / 5$ & 140615 GreenHaz. \\
T1 & M3 & 5.10 & $5 / 6$ & $3 / 4$ & $5 / 5$ & $14-1122$ SheepSk. \\
T2 & M3 & 5.10 & $5 / 6$ & 4 & $5 / 5$ & $14-1118$ Beige \\
T3 & M3 & 5.10 & 6 & 4 & $5 / 5$ & 436 GrayHues \\
& unmordant & 6 & $5 / 6$ & 4 & $4-4 / 5$ & 468 Cream \\
\hline
\end{tabular}

M1: $\mathrm{FeSO}_{4}$; M2: $\mathrm{CuSO}_{4}$; M3: Alum; T1: Pre-mord; T2:Together mord; T3: Lastmord. 
and put into dye-bath solution $(100 \mathrm{~mL})$. It was heated at $90{ }^{\circ} \mathrm{C}$ for $1 \mathrm{~h}$, at the end of the period, the dyed material removed, rinsed with distilled water and dried [15].

\subsubsection{Together-Mordanting Method}

Both mordant (in solid state which is equivalent to 0.1 M mordant solution) and dyestuff solution poured into a flask and the sample placed in this mixture. The complication was heated at $90{ }^{\circ} \mathrm{C}$ for $1 \mathrm{~h}$. After cooling, it was rinsed and dried [15].

\subsubsection{Last-Mordanting Method}

On the contrary to pre-mordanting method, the undyed material ( $1 \mathrm{~g}$ ) was first treated with dyestuff solution for $1 \mathrm{~h}$ at $90{ }^{\circ} \mathrm{C}$. After cooling the sample, it was rinsed with distilled water and put into $0.1 \mathrm{M}$ mordant solution $(100 \mathrm{~mL})$ and heated for $1 \mathrm{~h}$ at $90{ }^{\circ} \mathrm{C}$. Finally, the dyed material was rinsed with distilled water and dried [15].

For dyeing experiments, using $\mathrm{FeSO}_{4}$ wet, dry rubbing and washing fastness values are 4.5, approximately. Light fastness values are between 5 and 7. These results are acceptable as good. The dyeing made with $\mathrm{CuSO}_{4}$ all fastness values are perfect except for washing and light fastness. For the dyeing made with $\mathrm{AiK}\left(\mathrm{SO}_{4}\right)_{2}$, all results are 4 and over. Fastness values are 4 and over for unmordanting dyeings. Fastness values and color codes for dyed woollen fabrics are shown in Table 2.

In Table 1, it may be observed that the wash fastness values are low on dyeings with woollen fabrics using $\mathrm{FeSO}_{4}$ using pre- and together-mordanting, and other fastnesses are high. However, the wash fastnesses are low and other fastnessess are high for last-mordanting for $\mathrm{CuSO}_{4}$ mordant. In addition, the wash fastnesses are low and other fastnesses are high for pre-mordanting for $\mathrm{AiK}\left(\mathrm{SO}_{4}\right)_{2}$ mordant. Fastness values for unmordanted dyes are 4 and up. The fastness results and color codes of cotton fabrics pretreated with AUS mordant system are seen in Table 3.

The color has changed in the wash and light fastnesses dyed of cotton fabrics pretreated with AUS using $\mathrm{FeSO}_{4}$ mordant. However, all fastnesses were observed well for mordanted with $\mathrm{CuSO}_{4}$ for each three mordanting methods. For alum, wash fastnesses are very low in the pre- and together-mordanting and fastnesses are high. The fastness results and color codes of woollen fabrics pretreated with AUS mordant system are seen in Table 4.

The color has changed in the wash fastnesses dyed of woollen fabrics pretreated with AUS using $\mathrm{FeSO}_{4}$ mordant, and wash fastness is low. However, wash fastnesses were observed low in the together-mordanting, and is high in the pre- and last-mordanting procedures. For alum, wash fastness is low in the pre-mordanting and fastnesses are high in the together- and last-mordanting method.

\subsection{Determination of Color Performance}

The spectral reflectance measurements of the naturally dyed fabrics were determined using a Konica

Table 2 Fastness values and color codes of dyed woollen fabrics.

\begin{tabular}{lllllll}
\hline Method & Mordant & $\mathrm{pH}$ & Light & Wash & Rubbing (wet/dry) & Colorcode \\
\hline T1 & M1 & 4.65 & 6 & 3 & $5 / 5$ & CoolGray4/ GrayH. \\
T2 & M1 & 4.65 & $4 / 5$ & $2 / 3$ & $5 / 5$ & $421 /$ GrayHues \\
T3 & M1 & 4.65 & 6 & $4 / 5$ & $5 / 5$ & $401 /$ HrayHues \\
T1 & M2 & 4.01 & $5 / 6$ & $2 / 3$ & $5 / 5$ & WorwGray2/ GrayH. \\
T2 & M2 & 4.01 & 4 & $4 / 5$ & $5 / 5$ & $480 /$ ColoredGray \\
T3 & M2 & 4.01 & $6 / 7$ & $2 / 3$ & $5 / 5$ & $434 /$ GrayHues \\
T1 & M3 & 5.10 & $5 / 6$ & 2 & $5 / 5$ & $12-0812$ Alabaster \\
T2 & M3 & 5.10 & $5 / 6$ & 5 & $5 / 5$ & $436 /$ GrayHues \\
T3 & M3 & 5.10 & 6 & 4 & $5 / 5$ & $434 /$ GrayHues \\
& Un mord. & 6 & $5 / 6$ & $4 / 5$ & $5-4 / 5$ & 468 Spectralcolor \\
\hline
\end{tabular}

M1: $\mathrm{FeSO}_{4}$; M2: $\mathrm{CuSO}_{4}$; M3: Alum; T1:Pre-mord; T2: Together mord; T3: Lastmord. 
Table 3 Fastness results and colorcodes of cotton fabrics pretreated with AUS mordant system.

\begin{tabular}{lllllll}
\hline Method & Mordant & $\mathrm{pH}$ & Light & Wash & Rubbing (wet/dry) & Colorcode \\
\hline T1 & M1 & 4.65 & 5 & 5 & $4 / 5-5$ & 14-1122SheppSk \\
T2 & M1 & 4.65 & C.C & C.C & $4 / 5-5$ & 17-3906 Lilac Gr. \\
T3 & M1 & 4.65 & $6 / 7$ & 5 & $5 / 5$ & $14-1118$ Beige \\
T1 & M2 & 4.01 & 6 & 5 & $4 / 5-5$ & $401 /$ GrayHues \\
T2 & M2 & 4.01 & $6 / 7$ & 5 & $5 / 5$ & 479/Colorneutrals \\
T3 & M2 & 4.01 & $5 / 6$ & $3 / 4$ & $5 / 5$ & $14-0615$ Green Haz \\
T1 & M3 & 5.10 & 4 & 1 & $5 / 5$ & 150719 SilverFern \\
T2 & M3 & 5.10 & 5 & 2 & $5 / 5$ & 120715 DubleCream \\
T3 & M3 & 5.10 & 6 & 4 & $5 / 5$ & 468/ SpectralCol. \\
\hline
\end{tabular}

M1: $\mathrm{FeSO}_{4}$; M2: $\mathrm{CuSO}_{4}$; M3: Alum; T1: Pre-mord; T2: Together mord; T3: Lastmord; C.C: Colorchaged.

Table 4 Fastness results and colorcodes of woollen fabrics pretreated with AUS mordant system.

\begin{tabular}{lllllll}
\hline Method & Mordant & $\mathrm{pH}$ & Light & Wash & Rubbing (wet/dry) & Colorcode \\
\hline T1 & M1 & 4.65 & 5 & 2 & $5 / 5$ & $437 /$ GrayHues \\
T2 & M1 & 4.65 & C.C & C.C & $5 / 5$ & $429 /$ GrayHues \\
T3 & M1 & 4.65 & $6 / 7$ & 5 & $5 / 5$ & 141038 New Wheat \\
T1 & M2 & 4.01 & 6 & 5 & $4 / 5-4 / 5$ & $13-0840$ Snap D \\
T2 & M2 & 4.01 & $6 / 7$ & 3 & $5 / 5$ & 151305 FeatlonGrey \\
T3 & M2 & 4.01 & $5 / 6$ & 5 & $5 / 5$ & WarmGray $1 /$ GrayHues \\
T1 & M3 & 5.10 & 4 & $2 / 3$ & $5 / 5$ & $468 /$ SpectralColors \\
T2 & M3 & 5.10 & 5 & 5 & $5 / 5$ & $12-0720$ Yellow \\
T3 & M3 & 5.10 & 6 & 5 & $5 / 5$ & CoolGray $1 /$ GrayHues \\
\hline
\end{tabular}

M1: $\mathrm{FeSO}_{4}$; M2: $\mathrm{CuSO}_{4}$; M3: Alum; T1: Pre-mord; T2: Together mord; T3: Last mord; C. C: Colorchanged.

Minolta 3600d (Japan) spectrophotometer. Color strength was expressed as $\mathrm{K} / \mathrm{S}$ values of the dyed samples using the Kubelka-Munk equation:

$$
\mathrm{K} / \mathrm{S}=(1-\mathrm{R})^{2} / 2 \mathrm{R}
$$

where, $\mathrm{K}$ is the absorption coefficient, $\mathrm{R}$ is the reflectance of the dyed sample and $\mathrm{S}$ is the scattering coefficient.

$\mathrm{L} * \mathrm{a} * \mathrm{~b} *$ and $\mathrm{K} / \mathrm{S}$ values of cotton and woollen samples unpretreated with AUS are seen in Table 5.

As seen in Table 4, it was obtained in different shades of color intensity for cotton fabrics that un-pretreated with AUS. Pale brown color tones were obtained, generally. The value of $a^{*}$ is negative and the color has shifted to brown with iron sulfate in together-mordanting. The highest $\mathrm{K} / \mathrm{S}$ (14.64100) value was obtained from $\mathrm{FeSO}_{4}$ in the together-mordanting.

According to Table 4, it was obtained in different shades of color intensity for woollen fabrics that unpretreated with AUS, and pale brown color tones were usually obtained. The value of $\mathrm{a}^{*}$ is negative for $\mathrm{FeSO}_{4}$ in pre-mordanting and last-mordanting for $\mathrm{CuSO}_{4}$, and also the color has shifted to brown with iron sulphate in together-mordanting. The highest K/S (5.83947) value was obtained with $\mathrm{CuSO}_{4}$ in the together-mordanting.

The K/S and L*a*b* values of cotton and woollen fabrics pretreated with AUS mordant system are given in Table 6.

Different intensity and brighter color or color tones were obtained in the dyed cotton fabrics pretreated with AUS. Dark brown, pale yellow and gray color tones were obtained, generally. But, it was seen that $\mathrm{a}^{*}$ is negative and the brown color has shifted to yellow with iron sulphate in the together-mordanting with iron sulfate and in the pre- and last-mordanting methods with alum. In addition, it is seen that $L^{*}$ values indicate the brightness of the color and are positive for all results. The highest $\mathrm{K} / \mathrm{S}$ (13.10226) value was obtained from $\mathrm{FeSO}_{4}$ in the together-mordanting. 
Table $5 L^{*} a^{*} b^{*}$ and $\mathrm{K} / \mathrm{S}$ values of cotton and woollen samples unpretreated with AUS.

\begin{tabular}{|c|c|c|c|c|c|}
\hline Fabric & Mordant & $\mathrm{L}^{*}$ & $a^{*}$ & $\mathrm{~b}^{*}$ & $\mathrm{~K} / \mathrm{S}$ \\
\hline Cotton & $\mathrm{FeSO}_{4}$ & 51.09223 & 3.2135 & 12.6849 & 8.84863 \\
\hline " & $\mathrm{FeSO}_{4}$ & 39.3095 & -0.6640 & 5.7743 & 14.64100 \\
\hline " & $\mathrm{FeSO}_{4}$ & 59.8060 & 5.3438 & 22.4157 & 8.16812 \\
\hline$"$ & $\mathrm{CuSO}_{4}$ & 62.0611 & 1.8438 & 10.4227 & 3.37569 \\
\hline$"$ & $\mathrm{CuSO}_{4}$ & 51.4155 & 4.3418 & 11.2770 & 6.78419 \\
\hline " & $\mathrm{CuSO}_{4}$ & 69.9567 & 0.3674 & 9.5292 & 2.17486 \\
\hline " & $\mathrm{A} 1 \mathrm{~K}\left(\mathrm{SO}_{4}\right)_{2}$ & 67.2288 & 1.9543 & 13.8670 & 4.61283 \\
\hline " & $\mathrm{A} 1 \mathrm{~K}\left(\mathrm{SO}_{4}\right)_{2}$ & 71.2706 & 2.5159 & 11.1383 & 3.08468 \\
\hline$"$ & $\mathrm{~A} 1 \mathrm{~K}\left(\mathrm{SO}_{4}\right)_{2}$ & 75.2691 & 0.8701 & 7.4420 & 1.79238 \\
\hline Wool & $\mathrm{FeSO}_{4}$ & 64.2755 & -0.0560 & 5.1680 & 2.52778 \\
\hline " & $\mathrm{FeSO}_{4}$ & 66.9266 & 0.1076 & 5.2012 & 2.12176 \\
\hline$"$ & $\mathrm{FeSO}_{4}$ & 59.9216 & 0.2045 & 11.7485 & 5.41675 \\
\hline " & $\mathrm{CuSO}_{4}$ & 67.6697 & 1.4781 & 10.1613 & 2.16557 \\
\hline " & $\mathrm{CuSO}_{4}$ & 54.0520 & 4.0564 & 12.9811 & 5.83947 \\
\hline$"$ & $\mathrm{CuSO}_{4}$ & 70.3022 & -0.0153 & 8.1994 & 1.76316 \\
\hline$"$ & $\mathrm{~A} 1 \mathrm{~K}\left(\mathrm{SO}_{4}\right)_{2}$ & 72.7843 & 1.1865 & 12.0956 & 2.12717 \\
\hline " & $\mathrm{A} 1 \mathrm{~K}\left(\mathrm{SO}_{4}\right)_{2}$ & 72.6862 & 0.5437 & 12.1097 & 3.62508 \\
\hline " & $\mathrm{A} 1 \mathrm{~K}\left(\mathrm{SO}_{4}\right)_{2}$ & 73.8457 & 0.7376 & 7.9830 & 1.56455 \\
\hline Unmordantcotton & - & 70.7927 & 1.3369 & 9.0140 & 2.15633 \\
\hline Unmordantwool & - & 64.6099 & 0.9230 & 6.0552 & 2.18797 \\
\hline
\end{tabular}

Table $6 \mathrm{~K} / \mathrm{S}$ and $\mathrm{L}^{*} \mathrm{a} \mathbf{b}^{*}$ values of cotton and woollen fabrics pretreated with AUS.

\begin{tabular}{|c|c|c|c|c|c|}
\hline Fabric & Mordant & $\mathrm{L}^{*}$ & $a^{*}$ & $\mathrm{~b}^{*}$ & $\mathrm{~K} / \mathrm{S}$ \\
\hline Cotton & $\mathrm{FeSO}_{4}$ & 62.0317 & 4.4335 & 14.9665 & 4.51023 \\
\hline " & $\mathrm{FeSO}_{4}$ & 43.3952 & -0.2263 & 6.4611 & 13.10226 \\
\hline$"$ & $\mathrm{FeSO}_{4}$ & 64.0475 & 3.7366 & 17.9865 & 4.70666 \\
\hline$"$ & $\mathrm{CuSO}_{4}$ & 67.5247 & 1.5217 & 12.0265 & 2.85670 \\
\hline$"$ & $\mathrm{CuSO}_{4}$ & 62.1596 & 3.7720 & 11.2939 & 4.10011 \\
\hline " & $\mathrm{CuSO}_{4}$ & 69.4624 & 0.8745 & 9.7651 & 2.42581 \\
\hline$"$ & $\mathrm{~A} 1 \mathrm{~K}\left(\mathrm{SO}_{4}\right)_{2}$ & 70.5023 & -0.2614 & 18.4355 & 5.12383 \\
\hline$"$ & $\mathrm{~A} 1 \mathrm{~K}\left(\mathrm{SO}_{4}\right)_{2}$ & 76.2123 & 0.7283 & 11.3944 & 2.72599 \\
\hline$"$ & $\mathrm{~A} 1 \mathrm{~K}\left(\mathrm{SO}_{4}\right)_{2}$ & 82.1934 & -0.4548 & 4.9668 & 1.20333 \\
\hline Wool & $\mathrm{FeSO}_{4}$ & 58.5803 & 1.6201 & 8.2479 & 3.75245 \\
\hline$"$ & $\mathrm{FeSO}_{4}$ & 60.9987 & 0.4554 & 8.8697 & 3.64166 \\
\hline$"$ & $\mathrm{FeSO}_{4}$ & 75.0992 & 4.5935 & 17.4982 & 2.37183 \\
\hline$"$ & $\mathrm{CuSO}_{4}$ & 69.7200 & 1.0062 & 9.7359 & 2.03968 \\
\hline$"$ & $\mathrm{CuSO}_{4}$ & 65.6046 & 1.9249 & 10.0032 & 2.36547 \\
\hline$"$ & $\mathrm{CuSO}_{4}$ & 75.6441 & -0.6701 & 7.5391 & 1.43618 \\
\hline$"$ & $\mathrm{~A} 1 \mathrm{~K}\left(\mathrm{SO}_{4}\right)_{2}$ & 77.5878 & -0.2626 & 13.0513 & 1.87527 \\
\hline$"$ & $\mathrm{~A} 1 \mathrm{~K}\left(\mathrm{SO}_{4}\right)_{2}$ & 80.1996 & 0.2834 & 10.0228 & 1.58332 \\
\hline$"$ & $\mathrm{~A} 1 \mathrm{~K}\left(\mathrm{SO}_{4}\right)_{2}$ & 81.6957 & -0.2513 & 5.6013 & 0.90771 \\
\hline
\end{tabular}

As seen in Table 6, different intensity and brighter color tones were obtained in the dyed woollen fabrics pretreated AUS. Brown and gray tones were performed. But, it was seen that $\mathrm{a}^{*}$ is negative and the brown color has shifted to yellowish brown with copper sulfate in the last-mordanting and in the preand last-mordanting with alum. L* values indicate the brightness of the color and are positive for all results 
as well dyed cotton fabrics. The highest $\mathrm{K} / \mathrm{S}$ (3.75245)

value was obtained from $\mathrm{FeSO}_{4}$ in the pre-mordanting.

The K/S and $\mathrm{L}^{*} \mathrm{a} * \mathrm{~b} *$ values of cotton and woollen fabrics unpretreated with AUS are given in Table 7.

As seen in Table 7, different intensity and brighter color or color tones were obtained in the dyed cotton fabrics unpretreated with AUS. Brown tones were obtained, generally. The value of $\mathrm{a}^{*}$ is negative and the color has shifted to brown with iron sulfate. The highest $\mathrm{K} / \mathrm{S}$ (14.64100) value was obtained from $\mathrm{FeSO}_{4}$ in the together-mordanting.

Different intensity and brighter color or color tones were also obtained in the dyed wool fabrics unpretreated with AUS. Pale brown tones were obtained, generally. The value of $\mathrm{a}^{*}$ is negative and the color has shifted to brown with iron sulfate in the pre-mordanting and with copper sulfate in the last-mordanting. The highest $\mathrm{K} / \mathrm{S}(5.83947)$ was obtained from $\mathrm{CuSO}_{4}$ in the together-mordanting.

\section{Results}

Metal complex formation has been an outstanding property of textile dyeing from ancient times. This procedure increases the fastness of fabric and provides variety of colors.

$\mathrm{Al}$ (III) and Fe (II) ions have a coordination number of six and they are able to make complexes in the octahedral configuration. So, in the proposed mechanisms which are given in Fig. 1, the unoccupied sites of the metal ions may be occupied with $\mathrm{H}_{2} \mathrm{O}$ molecules, oxochrome groups of the dyestuff or free amino and carboxyl groups of wool fabric. Proposed mechanisms for dyeing of wool and cotton fabric with the extract of Alkanna orientalis roots are given in Figs. 1 and 2 [16].

Because the cotton has cellulosic structure, coordine covalent bonding occurs between $\mathrm{CH}_{2} \mathrm{O}$ groups of cellulose and metal cation. The suggested mechanism is given below (Fig. 2).

Table 7 K/S and L*a*b* values of cotton and woollen fabrics unpretreated with AUS.

\begin{tabular}{|c|c|c|c|c|c|}
\hline Fabric & Mordant & $\mathrm{L}^{*}$ & $a^{*}$ & $\mathrm{~b}^{*}$ & $\mathrm{~K} / \mathrm{S}$ \\
\hline Cotton & $\mathrm{FeSO}_{4}$ & 51.09223 & 3.2135 & 12.6849 & 8.84863 \\
\hline$"$ & $\mathrm{FeSO}_{4}$ & 39.3095 & -0.6640 & 5.7743 & 14.64100 \\
\hline$"$ & $\mathrm{FeSO}_{4}$ & 59.8060 & 5.3438 & 22.4157 & 8.16812 \\
\hline$"$ & $\mathrm{CuSO}_{4}$ & 62.0611 & 1.8438 & 10.4227 & 3.37569 \\
\hline " & $\mathrm{CuSO}_{4}$ & 51.4155 & 4.3418 & 11.2770 & 6.78419 \\
\hline$"$ & $\mathrm{CuSO}_{4}$ & 69.9567 & 0.3674 & 9.5292 & 2.17486 \\
\hline$"$ & $\mathrm{~A} 1 \mathrm{~K}\left(\mathrm{SO}_{4}\right)_{2}$ & 67.2288 & 1.9543 & 13.8670 & 4.61283 \\
\hline$"$ & $\mathrm{~A} 1 \mathrm{~K}\left(\mathrm{SO}_{4}\right)_{2}$ & 71.2706 & 2.5159 & 11.1383 & 3.08468 \\
\hline$"$ & $\mathrm{~A} 1 \mathrm{~K}\left(\mathrm{SO}_{4}\right)_{2}$ & 75.2691 & 0.8701 & 7.4420 & 1.79238 \\
\hline Wool & $\mathrm{FeSO}_{4}$ & 64.2755 & -0.0560 & 5.1680 & 2.52778 \\
\hline$"$ & $\mathrm{FeSO}_{4}$ & 66.9266 & 0.1076 & 5.2012 & 2.12176 \\
\hline$"$ & $\mathrm{FeSO}_{4}$ & 59.9216 & 0.2045 & 11.7485 & 5.41675 \\
\hline$"$ & $\mathrm{CuSO}_{4}$ & 67.6697 & 1.4781 & 10.1613 & 2.16557 \\
\hline$"$ & $\mathrm{CuSO}_{4}$ & 54.0520 & 4.0564 & 12.9811 & 5.83947 \\
\hline$"$ & $\mathrm{CuSO}_{4}$ & 70.3022 & -0.0153 & 8.1994 & 1.76316 \\
\hline$"$ & $\mathrm{~A} 1 \mathrm{~K}\left(\mathrm{SO}_{4}\right)_{2}$ & 72.7843 & 1.1865 & 12.0956 & 2.12717 \\
\hline$"$ & $\mathrm{~A} 1 \mathrm{~K}\left(\mathrm{SO}_{4}\right)_{2}$ & 72.6862 & 0.5437 & 12.1097 & 3.62508 \\
\hline$"$ & $\mathrm{~A} 1 \mathrm{~K}\left(\mathrm{SO}_{4}\right)_{2}$ & 73.8457 & 0.7376 & 7.9830 & 1.56455 \\
\hline Unmordantcotton & - & 70.7927 & 1.3369 & 9.0140 & 2.15633 \\
\hline Unmordantwool & - & 64.6099 & 0.9230 & 6.0552 & 2.18797 \\
\hline
\end{tabular}




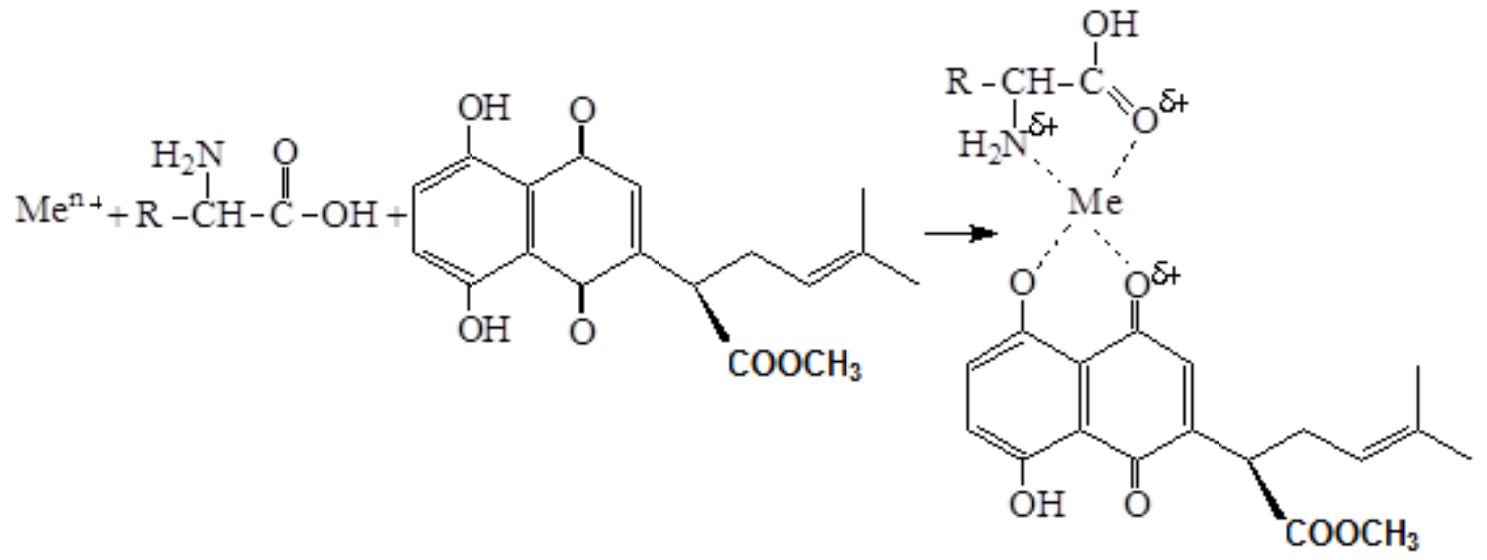

Fig. 1 The proposed dyeing mechanism of wool fabric with Alkanna orientalis roots extract.

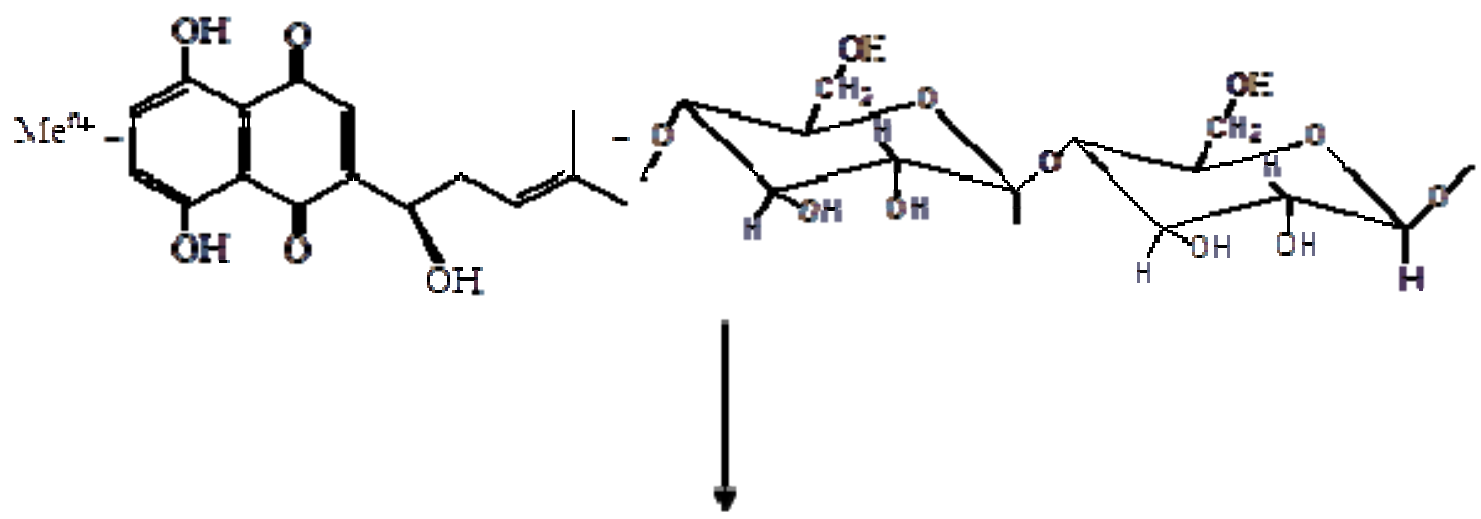

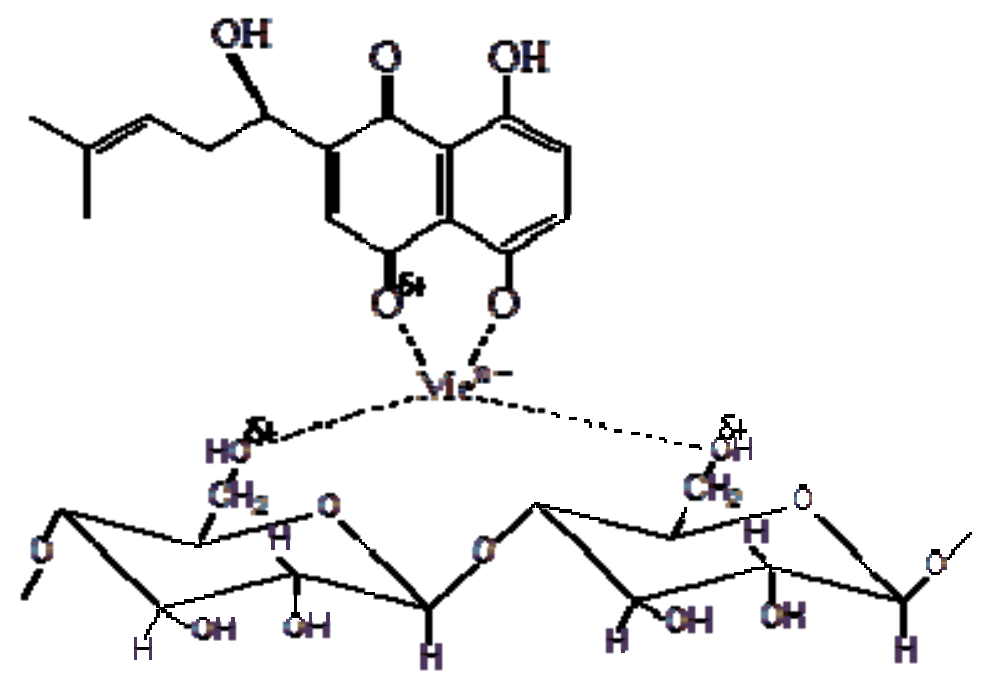

Fig. 2 The proposed dyeing mechanism of cotton fabric with Alkanna orientalis root extract.

\section{Conclusions}

In this study, the Alkanna orientalis roots were used for dyeing of wool and cotton fabrics. Natural dye solution was extracted and applied to the selected fabrics using pre-, together-, and last-mordanting techniques. Brown, yellow and beige color tones were obtained, usually. Fastness of color obtained using artifical urine system (AUS) was higher than other dyed samples which are unpretreated with AUS. We 
can say that the pre-treatment of fabrics with AUS increases the fastness. Here, amonia opens the micelles of the fabric, urea inreases the solubility of dye and oxalate improves the stability of metal complex [14].

The dyeing results of the study showed that Alkanna orientalis roots can be used as a natural dyestuff source in dyeing of cotton and wool fabrics with suitable mordant.

\section{References}

[1] Samanta, A. K., and Agarwal, P. 2009. "Application of Natural Dyes on Textiles." Indian Journal of Fibre \& Textile Research 34: 384-99.

[2] Kamat, S. Y., and Alat, D. V. 1990. "Natural Dyes-A Dying Craft?" The Indian Textile Journal 3 (6): 66-70.

[3] Glover, B. 1995. "Are Natural Colors Good for Your Health-Are Synthetic Ones Better.” Textile Chemist and Colorist 27 (4): 17-20.

[4] Smith, R., and Wagner, S. 1991. "Dyes and the Environmental Is Natural Better?" American Dyestuff Reporter 80 (9): 32-4.

[5] Moiz, A., Ahmed, M. A., Kausar, N., Ahmed, K., and Sohail, M. 2010. "Study the Effect of Metal Ion on Wool Fabric Dyeing with Tea as Natural Dye." Journal of Saudi Chemical Society 14 (1): 69-76.

[6] Raja, A. S. M., and Thilagavathi, G. 2008. "Dyes from the Leaves of Deciduous Plants with a High Tannin Content for Wool." Coloration Technology 124 (5): 285-9.

[7] Davis, P. H., Mill, R. R., and Tan, K. 1988. Flora of Turkeyandthe East AegeanIslands. V. 10. Edinburgh: University Press, 178-9.

[8] Oztav, F. 2009. Havacıva bitkisinin selülozik ve protein elyaf boyar maddesi olarak kullanılabilirliğinin araştırılması. Doktora tezi. Gaziosmanpaşa Üniv. Fen Bilimleri Enstitüsü, Kimya Anabilim dalı. ( In Turkish)

[9] Tawfik, W. A., Shams, K. A., Abdel-Azim, N. S., Hassan, N. M., and Ismail, S. I. 2007. "Naphthaquinones of Alkanna Orientalis (L.) Boiss." African Journal of Traditional, Complementary and Alternative Medicines 4 (1): 55-8.

[10] Ragaa, M., Mansour, A., and Saleh, M. 1986. "The Flavonoids of Alkanna orientalis." J. of Natural Products 49 (2): 356.

[11] Tappenier, J., Vasiliou, A., Ganzera, M., Fessas, D., Stuppner, H., Papagergiou, V. P., and Assimpolou, A. N. 2014. "Quantitative Determination of Alkannins and Ahikonins in Endemic Mediterranean Species." Biomedical Chromatgraphy (28): 923-33.

[12] Esfahani, H. M., Esfahani, Z. M., Degahki, N. K. Hosseini-Sharifabad, A., Tabrizian, K., Parsa, M., and Ostad, S. N. 2012. "Anti-inflammatory and Anti-nociceptive Effects of the Ethanolic Extracts of Alkanna Frigide and Alkanna Orientalis." J. of Nat. Med. 66 (3): 447-52.

[13] Ozgokçe, F., and Yilmaz, I. 2003. "Dyeplant of East Anatolia Region.” Economic Botany 57 (4): 454-60.

[14] Onal, A. 1996. "Extraction of Dyestuff from Onion (Alliumcepa L.) and Its Application in the Dyeing of Wool, Feathered-Leather and Cotton.” Turkish Journal of Chemistry 20 (3): 194-203.

[15] Onal, A. 2000. Dogal Boyar Maddeler. Gaziosmanpaşa Universitesi, Fen Edebiyat Fakültesi Yayınları. Yayın No. 07, Tokat, Turkey.

[16] Tutak, M., and Benli, H. 2011. "Colour and Fastness of Fabrics Dyed with Wallnut (Juglansregia L.) Basenatural Dyes." Asian Journal of Chemistry 23 (2): 566-8. 